\title{
VERBAL AND NONVERBAL ASPECTS IN REALIZING LANGUAGE POLITENESS IN THE FILM "SABTU BERSAMA BAPAK" MADE BY ADHITYA MULYA
}

\author{
By \\ Prima Gusti Yanti ${ }^{1}$, Deasy Wahyu Hidayati ${ }^{2}$, Nini Ibrahim ${ }^{3}$ \\ ${ }^{1,2,3}$ University of Muhammadiyah Prof. DR. HAMKA, East Jakarta, Jakarta, Indonesia \\ Email: 1prima gustiyanti@uhamka.ac.id, ${ }^{2}$ deasywhouhamka.ac.id
}

\begin{tabular}{|c|c|}
\hline Article Info & ABSTRACT \\
\hline $\begin{array}{l}\text { Keywords: } \\
\text { Verbal Aspect } \\
\text { Nonverbal Aspect } \\
\text { Language Politness } \\
\text { Film "Sabtu Bersama Bapak" }\end{array}$ & $\begin{array}{l}\text { This study aims to describe the verbal and nonverbal aspects of the Realization of } \\
\text { Language Politeness in the film "SabtubersamaBapak" by Adhitya Mulya and it was } \\
\text { designed by using a qualitative descriptive method with content analysis } \\
\text { techniques. This qualitative descriptive method is used to collect and compile data, } \\
\text { analyze and interpret data (Rukajat, 2018). By using a qualitative descriptive } \\
\text { method, the researcher simply analyzed data based on verbal and nonverbal } \\
\text { language politeness in the film "SabtubersamaBapak" by AdhityaMulya. The results } \\
\text { showed that the most dominant language politeness in verbal communication } \\
\text { appears in the film the film "Sabtu bersama Bapak" are sympathy and wisdom. } \\
\text { Meanwhile, language politeness in non-verbal communication is dominant in } \\
\text { kinesics, namely gestures, hands, head, and so on. }\end{array}$ \\
\hline
\end{tabular}

This is an open-access article under the $\underline{C C B Y-S A}$ license.

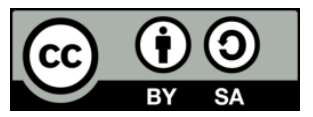

Corresponding Author:

Deasy Wahyu Hidayati,

University of Muhammadiyah Prof. DR. HAMKA, East Jakarta,

Jakarta, Indonesia

Email: deasy_wh@uhamka.ac.id

\section{INTRODUCTION}

Film prioritizes the existence and interest of stories that can invite many people to get involved. It combines entertainment and education, in other words, it can be used as media in education (Benny, 2020; Novianto, 2017). Film is as an educational media function to foster the younger generation in the formation of their own character.

Film can be inspired by social life. In this case, the film provides an overview of the reflection of the real world (Andalas, 2017). Through films, a person can stimulate and motivate desires in himself explain a message of good and bad in the story of a film, and can find out past conditions about the state of his nation. On the other hand, films can be understood and applied directly in their lives, such as speech, dress, attitude, and behavior.

Film raises social and cultural themes even though it is only in the form of engineering. Film is also able to become intermediaries to communicate the story when the film is made even though it was never intended for that (Wikyanto, 2018). Films are able to present concrete stories about people in a situation. In addition, it can also be used as an entertainer and provide more value for the audience. Apart from being entertaining, films also provide information and education. Films can influence and shape society based on the message behind it, without acting otherwise. 
Basically, film as an art has a strong influence in enriching one's life experience (Pratiwi, 2016). On the other hand, film has benefits in the world of education. Some assumptions think that film is a good education because it has entertainment, artistic, and direct communication values. In the 2013 Curriculum for learning Indonesian in high school, the main material about films is found in class XI Semesters 1 and 2, such as understanding, summarizing, comparing, and producing films. This shows that the film has a role in the learning process.

An educator must be able to choose a good film before it is given to students as an example or learning media. Choosing a good film is not an easy job. The process is to provide a positive picture to students regarding the material to be taught. This is considering that the film is depicted through audio and visual, which makes it easy to convey messages quickly to students (La Torre, 2014).

Based on a preliminary study of several students at the school, not a few children, teenagers, and even adults followed the development of the film's story. Interest in knowing the stories in films makes students take their time to watch films even though they are outside their age restrictions. Similarly, children under 13 can watch movies for teens over 13. Of course, this is one of the highlights for educators and parents. It is feared that this will have an impact on the results of the student's understanding.

On the other hand, the results of this preliminary study highlight the attitudes and behavior of students due to the influence of the films they watch which no longer heed the values of politeness. Like some of the scenes in television broadcasts (sinetron) teenagers who do not heed the values of customs and polite manners, both towards people who are older and younger. In addition, sometimes displays a form of bullying against colleagues and even educators at school. Incidents like this encourage teenagers to behave in a less polite (negative) direction. Thus, it is not only parents who educate wrongly, but the surrounding environment and mass media also affect its current development.

Seeing the social phenomena above, language politeness must be considered in today's life. Language politeness is seen as a form of speech that does not hurt the listener's feelings in social interaction (Leech, 2014). Thus, language politeness pays attention to speech and shows attitudes that contain polite or ethical values in everyday interactions.

Polite language can be seen verbally and nonverbally. Mulyana in Ngalimun (2017), views verbal language politeness as seen from the symbols of one or more words used. Meanwhile, nonverbal language politeness can be seen from the description of communication events that are conveyed outside the spoken or written word. Thus, language politeness in verbal and non-verbal communication can be separated, however, they are bound together, and sufficient in the communication carried out.

The politeness of the language used in verbal communication used must be in accordance with the principles of language politeness. This can be seen by Leech (2014), namely tact (wisdom/wisdom), generosity (acceptance/praise), approbation (generosity), modesty (humility), agreement (agreement), and sympathy (sympathy). On the other hand, nonverbal language politeness can be seen by Brown in Meidyastuti, et al, (2020) from the kinesics, eye contact, proxemic, artifact, kinesthetic, and olfactory dimensions.

The politeness of language can also be seen from a gentle and kind attitude from the point of view. grammar. as well as student behavior (Kemendiknas, 2010). Students should be taught politeness attitudes, especially matters related to language politeness. Educators and parents pay attention and remind students to always be polite in acting, speaking, and dressing. In this case, students' politeness in communicating can also be implemented through screening or watching quality films.

Important language politeness principles are given to students and can be used as material targets in classroom learning. By incorporating the principles of politeness in learning Indonesian in high school, students will better know and understand how to communicate and behave in accordance with polite manners by using appropriate diction and being polite verbally and nonverbally between students and teachers, and vice versa in the process of teaching and learning activities.

Research related to using films as research objects has been carried out by Wulansafitri and Syaifudin (2020) with the title Language Politeness in My Stupid Boss 1, Film Dialogue with a qualitative descriptive method. The results showed that from 57 data, there were 19 data complying with the politeness principle, 38 data violating the politeness principle, and 15 implicatures that appear. The next research was conducted by Meidyastuti, et al, (2020) entitled The Meaning of Nonverbal Messages in the Larva Cartoon Show Season 3 in Garlic episodes 1 and 2 with a descriptive method. The results of the study explain that the meaning of nonverbal messages shown in 
International Journal of Social Science (IJSS)

Vol.1 Issue.5 February 2022, pp: 791-798

ISSN: 2798-3463 (Printed) | 2798-4079 (Online)

DOI: https://doi.org/10.53625/ijss.v1i5.1324

the cartoon Larva season 3 episodes Garlic 1 and Garlic 2 is also reflected in the problems that exist in life today such as struggling, respecting, being serious, and being patient.

The research conducted by Wulansafitri and Syaifudin (2020) and Meidyastuti, et al, (2020) has similarities in this study, namely both using film as the object of research and using descriptive methods as an analytical tool. It's just that Wulansafitri and Syaifudin's (2020) research, only discusses forms of violation of the maxim of politeness in language, in contrast to this study which discusses politeness in terms of the maxims of Leech's theory. Then in Meidyastuti's research, et al, (2020) also has a difference by only discussing the nonverbal aspect, while this study discusses verbal and nonverbal language politeness.

One of the films that can be studied is the film "SabtuBersamaBapak"made byAdhityaMulya. This film belongs to the entertainment genre and is for ages 13 and up. In addition, this film has 639,530 viewers and is included in the category of the top 15 Indonesian films in 2016. The film "SabtuBersamaBapak" can be used as material to be studied and researched. This is also in order to see the film "SabtuBersamaBapak" can be used as a tool or media that is suitable in education and learning, especially for educators.

The film "Sabtu Bersama Bapak" is seen from the dialogues spoken by the characters as well as the verbal and nonverbal behavior shown by the characters, it is very interesting to study from the point of view of politeness which can provide learning about how to behave, behave, and speak well for today's students. This is the reason and purpose of the author to use the film "SabtuBersamaBapak" made byAdhityaMulya as the object of research.

\section{RESEARCH METHOD}

This study was designed using a qualitative descriptive method with content analysis techniques. This qualitative descriptive method is used to collect and compile data, analyze and interpret data (Rukajat, 2018). With a qualitative descriptive method, the researcher only analyzed data based on verbal and nonverbal language politeness in Adhitya Mulya's Saturday Together Film.

The data of this study include the contents of the film as seen from verbal politeness which includes wisdom/wisdom, acceptance/praise, generosity, humility, agreement, and sympathy). Then proceed with nonverbal politeness such as eye contact, proxemic, artifact, and kinesthetic. Meanwhile, the source of data in this study is in the form of speech/dialogue and behavior performed by all characters in the film.

The step of this research is by listening repeatedly to the film "SabtuBersamaBapak" with DVD or other media. After that, data transcription was carried out to obtain data that was in accordance with the research study followed by identifying data in the form of research studies such as verbal and nonverbal politeness. Then, activities were also carried out to record and classify the data that had been found into research analysis tables interpret them, and ended with drawing conclusions and presenting the research findings.

\section{RESULTS AND ANALYSIS}

The results of this study can be seen from the speech/dialogue and the behavior performed in the film analyzed verbally and non-verbally language politeness. The following analysis results can be presented.

\section{Verbal Politeness with the Principle of Wisdom/Wisdom}

Wisdom/ local wisdom are expressed by impositive and commissive dialogue.

[1] Bapak: (In the study, recording) "Satya, Saka, this is Mr. I just moved to another place; I didn't leave you. But we promise one thing, you will be good children, study diligently, and obey to mama ".

In the monologue above, judging from verbal politeness, the dialogue adheres to politeness that contains wisdom, namely the father who gives advice to his children through video recordings. Judging from the meaning, a father who loves his two children so much, but he doesn't have a long time. Therefore, with his wisdom/wisdom, Bapak started his video recording which contained advice for his two children and stated that "..... Bapak just moved to another place. Bapak didn't leave you ..." This shows that he will always be there for his children.

[2] Ibu. Itje: "I will take them to get married. I promise Kang. ."

In the dialogue fragment above, seen from verbal politeness, the dialogue obeys politeness which contains Ibu Itje's wisdom, namely giving the wisdom to share tasks with her husband when Mr. Itje has to leave Mrs. Itje and her two children. Judging from the meaning that Mrs. Itje gave a calm answer to Mr.'s concern because he could not bring his two children to the wedding. Therefore, Mrs. Itje answered, "I will get them married. I promise Kang ..." This is what becomes politeness in a husband-and-wife couple.

Verbal Politeness with the Praise Principle 
Praise is expressed with expressive and assertive dialogue.

[3] Bapak: "I'm proud of you, the same as you. You know, from a young age you must have been a champion. Thank you for making me proud... "

In the part of your dialogue, seen from his verbal politeness, his dialogue obeys politeness that contains praise, namely the father gives words for the hard work or awards that his two children have received. Judging from the meaning, the father in the recording is already sure that his children will be able to win a championship or achievement even without him accompanying them until they grow up.

[4] (In the video) Bapak monolog: Bapak loves you. (While looking at the camera affectionately) Remember one thing, in our family, the first and last person to believe in us is ourselves. This is for you too. Your food is delicious. (With a small smile) Trust me. When are you going to open your own restaurant?

In Bapak's monologue above, judging from his verbal politeness, his speech obeys politeness that contains wisdom and praise, namely father who really loves his two children to be able to grow without lack of advice from his father and gives praise to his wife, Mrs. Itje, for opening a restaurant because of her delicious food.

\section{Verbal Politeness with the Principle of Generosity}

The principle of generosity is conveyed in the form of commissive and impositive dialogue.

[5] Eh, Kang, I'm cooking something for you Kang... that's really great. Guess what?

In Rissa's dialogue, judging from verbal politeness, her dialogue is included in generosity and sympathy, namely Rissa who has an obligation to serve her husband, trying to make dishes for Satya and besides that, it appears that Rissa never stops trying to make delicious dishes, which are similar to Mother's cooking. his mother-inlaw, Mrs. Itje.

[6] Oh mamaaaa... the Saka masses here are forbidden? Who will take care of mom then?

In Saka's dialogue, judging from his verbal politeness, his dialogue includes generosity and sympathy, namely Saka who feels that it is his duty to take care of his mother and Saka is worried that Itje's mother will feel lonely and no one will take care of her.

Verbal Politeness with the Principle of Humility

Humility is expressed in expressive and assertive speech.

[7] Satya: "I'm sorry, all this time I was stupid"

Rissa: "No, Kang. It was my bad... "

In this fragment of Satya's dialogue, judging from his verbal politeness, his dialogue obeys politeness which contains Satya's humility, namely apologizing to Rissa (his wife) and admitting that he has been stupid all this time.

[8] If Satya finds out, he will be grumpy far away there. Meanwhile, if Saka finds out, later he will want to take care of me instead of looking for a mate.

In Ibu Itje's dialogue, seen from verbal politeness, her dialogue adheres to politeness which contains wisdom, humility, and sympathy, namely Ibu Itje feels that she does not want to be a burden to her children. Ibu Itje felt sympathy for any problems that would later be experienced by her children after they learned the truth that Ibu Itje was suffering from a serious illness.

Verbal Politeness with the Principle of Agreement

The agreement is expressed by expressive and assertive speech.

[9] Satya: "Let me do the work, even though it's far away, even though it's dangerous, but let me take the risk. So that you don't have to take any risks... just accept that you're done. My dad can't do it, I can't do it..."

Rissa: "Okkkeehhh....."

In the dialogue fragment above, seen from verbal politeness, his dialogue obeys politeness which contains an agreement, namely Satya who states that he is the only one who works, Rissa as a wife agrees with what her husband says.

[10] Saka: “.... I want to invite you to lunch ..." Ayu: "O....key. Ummm, it's half past 12, Mas."

In the dialogue fragment of Saka and Ayu above, judging by their dialogue, they obey the politeness that contains an agreement, namely Saka who invites Ayu to have lunch together and Ayu agrees to Saka's invitation.

Verbal Politeness with the Sympathetic Principle

Sympathy is expressed by expressive and assertive speech.

[11] Rissa: "I just want to help you .. Kang" 
International Journal of Social Science (IJSS)

Vol.1 Issue.5 February 2022, pp: 791-798

ISSN: 2798-3463 (Printed) | 2798-4079 (Online)

DOI: https://doi.org/10.53625/ijss.v1i5.1324

In Rissa's dialogue, seen from verbal politeness, her dialogue obeys politeness that contains sympathy, namely Rissa who feels sympathy for her husband who works too hard and is far away.

[12] Saka: "Wati, listen carefully, okay? Not all women want material like you.... "

In the dialogue fragment above, judging from verbal politeness, the dialogue obeys politeness that contains sympathy, namely Wati, who lives a luxurious life and always attaches importance to material things, Saka as the boss reminds Wati not to do that.

Nonverbal Politeness with Kinesik

Kinesics can be seen from body position and body movements in a distinctive but clearly defined way.

[13] Ibu Itje: (Physical/nonverbal movements) Sitting watching your video/recording, while embracing her two children (Satya and Saka) with a slightly smiling face.

In the physical movements performed by Mrs. Itje, seen from nonverbal politeness, her physical movements contain kinesic politeness, namely Mrs. Itje's hands which are directed to the arms of her two children to be embraced/hugged to the shoulders of Ibu Itjie. This is categorized as polite because it sees the relationship between the two, namely the mother and biological child.

[14] If Satya finds out, he will be in a bad mood there. If Saka finds out, later he wants to take care of me instead of looking for a mate.

In the physical movements carried out above, seen from nonverbal politeness, obey kinesic politeness, namely head movements that slightly point towards Bibi when speaking. This is categorized as polite by the speech and physical behavior shown by Mrs. Itje to Bibi.

Nonverbal Politeness with Eye Contact

Eye contact between two participants in a conversation has a cue as well. Through the eyes can hint at some meaning or meaning.

[15] Satya: (physical/nonverbal movement) .... was serving guests, suddenly he stopped in front of a woman with bangs and fell silent, and was stunned to see the woman, continued to stare without saying.

In the physical movements performed by Satya, judging from the nonverbal politeness, his physical movements contain eye contact politeness, namely Satya who suddenly stops in front of a woman with bangs, of course, it has a meaning, namely the feeling of liking or falling of Satya's heart for the beautiful woman. However, judging from the nonverbal politeness of eye contact, Satya's physical movements can be categorized as less polite. It can be argued that people who look at each other and are not at a close distance are not appropriate to stare at each other without words.

[16] Wati....... listens carefully, okay? Not all women want material like you...

Seeing Satya's physical movements, seen from nonverbal politeness, Saka's movements adhere to eye contact politeness, namely Saka's gaze at Wati is a gaze full of wisdom/wisdom and shows a form of Saka's sympathy for his employee named Wati.

Nonverbal Politeness with Proxemic distances

Proxemics can be studied with other nonverbal communicative categories that take into account acceptable

[17] Bapak: " I'm sorry, Neng..." (Besides Ibu Itje, right-hand hugs Ibu Itje and the left-hand holds Ibu Itje)

In the physical gesture above, judging from nonverbal politeness, the physical movement contains proxemic politeness, namely the closeness or distance between Bapak and Ibu Itje dialogue and view to talk about personal matters, which is only less than $10 \mathrm{~cm}$. This is categorized as having politeness because it sees the relationship between the two, namely spouses.

[18] Anyway, you must be cool!! Are you losing style with an intern who is paid with a meal coupon??

The physical movement above is seen from nonverbal impoliteness. Firman's impoliteness is supported by his kinesics, namely the movement of his hands and body that are moved directly towards Saka.

Nonverbal Politeness with Artifacts

A multicultural conversation group considered that artifacts and gestures could be significant factors for identifying general personality and mood characteristics. For example, clothes and jewelry that describe communication with a certain atmosphere and meaning.

[19] Saka: (Smiles broadly) mmmm... Mas, Mba. Sorry. So just take this one. (Only give one shirt that he wants to buy and ignore the other shirts that have been chosen by his friends).... 
The clothing or jewelry that appears in the piece of physical movement,seen from the nonverbal form, is included in the politeness of the use of artifacts or clothes and jewelry used by Saka. A director, Saka is a simple person, as evidenced by the clothes he wanted to buy. He only bought one shirt even though he had plenty of money to buy another shirt.

[20] 7 times 9, sixty-three. Good. Yess... Woww 100s for Ryaan (While giving scribbles on Ryan's work)

That's great, hug mommy first. (Hug Ryan) That's okay, the math...

In the clothes or jewelry that appears in the fragment of the physical movement, the physical movement is in the form of an artifact that adheres to nonverbal politeness. Based on her actions, Rissa stood next to Ryan and Miku at a close distance and moved her hand towards Ryan's head, besides, the clothes that Rissa wore when she was at home as a housewife, she never followed the clothes or culture in France. This shows that Rissa is a simple and polite person.

\section{Nonverbal Politeness with Kinesthetic}

Kinesthetic is a form of nonverbal communication that is carried out through hand movements, body expressions in order to obtain physical information such as touching. In some cultures, touch implies a very personal and intimate style, while in other cultures touching in a broad sense is normal.

[21] Rissa: "Yes, I want to. Come on, kiss me first." (Smiling, kissing Satya, and holding his hands)

In the physical movements performed by Rissa, seen from nonverbal politeness, the physical movements contain kinesthetic, namely the touch given by Rissa as Satya's wife to be. He accepted Satya's proposal and his happiness was expressed with a touch of a kiss. This is categorized as not having politeness because the physical movements they do are in public, so there is a possibility that various guests or other parties are watching.

[22] Ice cream? Of course ... okay.

In the physical movements carried out above, judging from the nonverbal politeness, Miku's dialogue is accompanied by a kinesik head movement facing Rissa, even though when we see the place where the dialogue is taking place, namely on the road (crossing) and Rissa holding the hands of her two children when they want to cross the road.

\section{DISCUSSION}

The number of politeness found in the film "SabtuBersamaBapak", is 454 data. Verbal politeness consists of 297 data which is divided into 6 parts, namely sympathy and wisdom/wisdom dominates in the film Sabtu Bersama Bapak which is 60 politeness data and 82 sympathy data, for politeness acceptance/praise has 27 data, for generosity, it has 22 politeness data, humility consists of on 48 politeness data and for agreement consists of 58 politeness data. Meanwhile, the number of nonverbal politeness consists of 157 data which is divided into 5 parts, namely kinesics which amounts to 70 data of politeness, eye contact which amounts to 27 data, proxemics totaling 30 data, artifacts totaling 10 data, and finally kinesthetic which amounts to 20 data.

Language politeness in verbal communication that most dominantly appears in the film Sabtu Bersama Bapak is sympathy and wisdom/wisdom. While language politeness in nonverbal communication is dominant in kinesics, namely body movements, hands, head, and so on.

Language politeness can be used as a strategy or a way for someone to use language. In this case, the language that is communicated is careful, kind, gentle, polite, and courteous language with the interlocutor (Anisa, 2017). On this side, politeness refers to the language rules used by the community. These rules are in accordance with the rules of etiquette that apply in a particular society that prioritizes polite language.

Politeness in communication is carried out in two directions (Wei, et.al., 2019), especially in filming. In the film, it is said that communication occurs when there is a similarity of meaning understood between the speaker and the listener or interlocutor (Desy, 2018). If this happens, then the establishment of effective communication. On the other hand, if the topic of conversation and the knowledge of the communicant are different from each other, it will cause discontinuity and difficulty in understanding and translating the content of the film's story as well as the information and messages that talked about (Suryanto, 2015).

Effective communication must reflect the politeness of language users. The politeness of language must also be contained in every dialogue he plays. Dialogue can be understood not only through verbal communication but requires a set of verbal communication to support a coherent plot or story content. For that, verbal communication is needed in a film.

In order for communication (dialogue) to be effective, speakers and listeners (players) must have verbal and nonverbal communication skills based on the principles of linguistic politeness. In language politeness, it can be said 
International Journal of Social Science (IJSS)

Vol.1 Issue.5 February 2022, pp: 791-798

ISSN: 2798-3463 (Printed) | 2798-4079 (Online)

DOI: https://doi.org/10.53625/ijss.v1i5.1324

that verbal communication is the main means of communicating, while nonverbal language is the supporting language of verbal language itself (Desy, 2018). Nonverbal communication includes gestures, tone, facial expressions, behavior, jokes, the language of touch, eye contact, and others (Abubakar, 2021). For this reason, presenting a film play is not only focused on the dialogue that is delivered but requires several things, such as expressiveness, eye contact, gestures, eye views, and attitudes that support the dialogue.

Verbal communication is needed in films because it is used as oral communication that utilizes language symbols in the form of speech (Desy, 2018). This is in accordance with the results of research by Abubakar (2021), which shows that verbal communication requires the use of words, vocabulary, and other symbols. Meanwhile, nonverbal communication must also be considered in the film, because it is seen as a supporter of verbal communication (Meidyastuti, et al, 2020). In this case, nonverbal communication is not solely through body movements or gestures, but facial expressions that are displayed when verbal communication is carried out. Thus, in communication, nonverbal symbols are used to emphasize verbal symbols (Desy, 2018; Meidyastuti, et al, 2020).

In improving language politeness, a person is able to send and capture messages both verbally and nonverbally. Verbal politeness can be captured through graphic symbols that are heard or spoken. In this case, verbal politeness must be supported by non-verbal politeness. This is confirmed by his Supractice in Desy (2018) which confirms that nonverbal politeness supports a person in capturing information or messages verbally. In other words, these verbal messages communicate a person's various feelings in communicating such as accepting or rejecting, agreeing, or rejecting, and so on.

\section{CONCLUSION}

Verbal politeness is seen as politeness seen from the direct speech of the speaker of the language. Through this direct speech, someone will easily give an assessment to others about whether or not they are polite in communicating, especially in a film. Verbal language is also able to provide a description of the character, attitude, or nature of the speaker, such as having wisdom/wisdom and sympathy in a person. Meanwhile, nonverbal politeness is seen as politeness that is expressed through physical movements or someone's behavior in carrying out dialogue. In this case, kinesics, as a physical movement or behavior performed, will be reinforcement or a balancer of verbal speech or dialogue in the film. Like kinesics in the form of body movements or gestures that are played.

On the other hand, the film "Sabtu Bersama Bapak" is worthy and complete to be used as a medium for learning Bahasa. The use of polite language, the use of clothing or jewelry that is suitable for all ages makes the film "Sabtu Bersama Bapak" acceptable to all groups. Not only that, this film has many messages that are conveyed implicitly or explicitly that can be accepted by all age groups. This is the agreement between the screenwriter (Adhitya Mulya), the film producer, and the director who from the beginning made this film to be loved by all parties.

\section{REFERENCES}

[1] Abubakar, G. F., Lasut, T. M., \& Rambing, R. (2021). Ekspresi Verbal dan Nonverbal dalam Mengungkapkan Ketakutan dan Kemarahan dalam Film Ready or Not oleh Bettinelli-Olpin, Tyler Gillet (Analisis Psikolinguistik). Jurnal Elektronik Fakultas Sastra Universitas Sam Ratulangi, 25.

[2] Andalas, E. F. (2017). Eskapisme Realitas dalam Dualisme Dunia Alice Telaah Psikologi-Sastra Film Alice in Wonderland (2010). KEMBARA: Jurnal Keilmuan Bahasa, Sastra, dan Pengajarannya, 3(2), 185-195.

[3] Anisa, E. P., Kiska, N. D., Maskanah, H., Kuntarto, E., \& Novianti, S. (2017). Kesantunan Berbahasa.

[4] Benny, B. (2021). Perancangan Simulasi Kampus STMIK IBBI Berbasis Multimedia dengan Metode Multimedia Development Life Cycle. Jurnal Ilmiah Core IT: Community Research Information Technology, 9(1).

[5] Brown, Douglas. 2007. Prinsip Pembelajaran dan Pengajaran Bahasa. Edisi kelima. Jakarta: Kedutaan Besar Amerika Serikat.

[6] Desy, M. (2018). Pengaruh Komunikasi Interpersonal Dalam Kegiatan Belajar-Mengajar antara Guru dan Murid KB/TK Islam Bunga Harapan Kecamatan Ngaliyan Semarang Terhadap Proses Pembentukan Karakter Anak. Majalah Ilmiah Inspiratif, 3(6).

[7] La Torre, M. (2014). The economics of the audiovisual industry: Financing TV, film and web. Springer Nature.

[8] Leech, G. (2014). The Pragmatics of Politeness. UK: Oxford University Press. 
[9] Meidyastuti, R. T., Jupriono, J., \& Rusmana, D. S. A. (2020). Makna Pesan Nonverbal dalam Tayangan Kartun Larva Season 3 Episode Garlic 1 dan 2. Jurnal Representamen, 6(01).

[10] Ngalimun. (2017). Ilmu Komunikasi Sebuah Pengantar Praktis. Yogyakarta: Pustaka Baru Press.

[11] Novianto, F. (2017). Penyutradaraan Film Televisi" Mila" Dengan Pendekatan Realisme (Doctoral dissertation, Institut Seni Indonesia Yogyakarta).

[12] Pratiwi, Y. (2016). Film animasi cerita dengan konteks multibudaya untuk mendukung pengembangan kekritisan penalaran anak usia SD. LITERA, 15(2), 292-304.

[13] Rukajat, A. (2018). Pendekatan penelitian kuantitatif: quantitative research approach. Deepublish.

[14] Suryanto. 2015.Pengantar Ilmu Komunikasi.Bandung:CV Pustaka Setia

[15] Tim PenyusunKemendiknas. 2010. Panduan Pelaksanaan Pendidikan Karakter. Jakarta: Kementerian Pendidikan Nasional Badan Penelitian dan Pengembangan Pusat Kurikulum dan Perbukuan.

[16] Wei, S., Zou, Y., Zhang, X., Zhang, T., \& Li, X. (2019). An integrated longitudinal and lateral vehicle following control system with radar and vehicle-to-vehicle communication. IEEE Transactions on Vehicular Technology, 68(2), 1116-1127.

[17] Wikayanto, A. (2018). Representasi Budaya Dan Identitas Nasional Pada Animasi Indonesia. In International Conference ARTESH (Vol. 2018, No. 3).

[18] Wulansafitri, I., \& Syaifudin, A. (2020). Kesantunan Berbahasa dalam Tuturan Film My Stupid Boss 1. Jurnal Sastra Indonesia, 9(1), 21-27. 